\title{
Arterial Segment
}

National Cancer Institute

\section{Source}

National Cancer Institute. Arterial Segment. NCI Thesaurus. Code C116116.

A segment of a blood vessel that is part of the arterial system. 